\title{
Comparison of early and late intravenous infusion of milrinone in pediatric patients undergoing cardiac surgery
}

Rabie Soliman ${ }^{1,3 *}$, Hassan Yousef ${ }^{2,3}$, Adel Ragheb ${ }^{3}$, Howaida Alqethamy ${ }^{3}$, Faisal Alghadam ${ }^{3}$ and Galal Elgamal ${ }^{3}$

\begin{abstract}
Objective: This study was done to compare the effects of early and late use of milrinone in pediatric patients undergoing complex cardiac surgery.

Design: The study was a prospective randomized study. Setting: Prince Sultan cardiac center, Saudi Arabia.

Methods: A prospective study involved 40 pediatric patients undergoing congenital corrective cardiac surgery, classified randomly into two groups $(\mathrm{N}=20)$. Group A: Milrinone infusion was started without loading dose, at $0.5 \mathrm{mcg} / \mathrm{kg} / \mathrm{min}$ at the beginning of CPB and continued postoperatively $(0.5-0.75 \mathrm{mcg} / \mathrm{kg} / \mathrm{min})$ in the PCICU. Group B: Milrinone was started as a loading dose $50 \mathrm{mcg} / \mathrm{kg}$ over $10 \mathrm{~min}$ after aortic declamping and continued as infusion $(0.5-0.75 \mathrm{mcg} / \mathrm{kg} / \mathrm{min})$ postoperatively in the PCICU. Data were collected at baseline, $1^{\text {st }}, 6^{\text {th }}, 12^{\text {th }}$, and $24^{\text {th }}$ postoperative hours in the ICU.

Results: The inotropic supports and mechanical supports were needed more in group B than group A. The comparison of heart rate, CVP, temperature, hemoglobin, $\mathrm{SpO} 2$ and $\mathrm{PaCO} 2$, were insignificant between the two groups $(\mathrm{P}>0.05)$. The mean arterial blood pressure through the first 6 hours postoperatively was higher in group $A$ than group $B(P<0.05)$, but became insignificant through other timepoints. The urine output and central venous oxygen saturation were higher in group $A$ than group $B(P<0.05)$. The serum lactate levels were significantly higher in group $B$ more than group $A(P<0.05)$.

Conclusion: early use of milrinone, lead to easy weaning from CPB, decreased requirement of pharmacological and mechanical support and decreased the incidence of low cardiac output syndrome after pediatric cardiac surgery and there was no complications related to milrinone in our study patients.
\end{abstract}

Keywords: pediatric patients, inotropes, milrinone, low cardiac output syndrome

\section{Introduction}

Several studies have documented the predictable fall in cardiac output, referred to as low cardiac output syndrome (LCOS), which occurs after congenital heart surgery. Causes of LCOS after cardiac surgery are multifactorial, including myocardial ischemia during aortic cross clamping, the effects of cardioplegia, activation of the inflammatory and complement cascades, and alterations in systemic and pulmonary vascular activity [1]. Residual cardiac lesions, even when minor, may also adversely impact the postoperative course. Because LCOS is common and contributes to postoperative morbidity and mortality, prevention of this predictable hemodynamic deterioration may have significant implications for clinical outcome. Preventing LCOS may impact hospital length of stay and may decrease the risk for postsurgical, nosocomial, and central nervous system complications. Traditionally, inotropic agents and vasodilators have been used to enhance tissue perfusion and facilitate postoperative recovery [2-4].

\footnotetext{
${ }^{*}$ Correspondence: rabiesoliman@hotmail.com

${ }^{1}$ Cairo university Egypt.

Full list of Author information is available at the end of the Article
}

Traditionally, catecholamines such as dopamine, dobutamine, epinephrine, and norepinephrine have been used for their positive inotropic effect in children with low cardiac output. These agents, however, produce several undesirable effects, including an increase in heart rate and myocardial oxygen consumption, an increase in systemic vascular resistance and, down-regulation of beta-adrenergic receptors in patients with preexisting heart failure. Unlike the catecholamines, milrinone produces a positive inotropic effect with concurrent vasodilatation and little chronotropic effect. As a result of these differences, milrinone has become a valuable tool in the treatment of children following cardiac surgery and in the management of shock $[5,6]$.

\section{Pharmacology of milrinone}

Milrinone, is a phosphodiesterase-3 inhibitor with inodilating and lusitropic properties independent of alpha and beta receptors $[7,8]$ Its direct myocardial effect is related to the increase in intracellular cyclic adenosine monophosphate with a subsequent increase in intracellular calcium levels and increased sensitivity of the actin-myosin complex to calcium. This leads to increased myocardial contractility. Concomitant activation of phospholamban by cyclic adenosin monophosphate accelerates removal of calcium from cytosol by the sarcoplasmic 
Soliman et al. Journal of Anesthesiology and Clinical Science 2012,

reticulum, thus shortening contraction time and leaving more time for myocardial relaxation in each cardiac cycle $[9,10]$. Milrinone can also theoretically exert an inotropic effect through its myocardial sarcoplasmic reticulum calcium release channel opening independent of phosphodiesterase-3 inhibition [11]. The direct vasodilating effect on peripheral and coronary circulation is related to the increased levels of cyclic guanosine monophosphate in vascular smooth muscle cells under phosphodiesterase-3 inhibitor treatment [12]. The drug is primarily (85\%) cleared through renal secretion, with $15 \%$ undergoing glucuronidation, and is $70 \%$ protein bound $[13,14]$. Milrinone is a drug commonly used to support cardiac output after congenital heart surgery in neonates, infants, and children. Pharmacokinetic studies suggest that milrinone clearance is greater and its volume of distribution larger in children than in adults $[3,15]$, but infants appear to have lower milrinone clearance than children [3].

The purpose of the study was to compare the effect and safety of early and late intraoperative uses of milrinone in pediatric patients undergoing complex cardiac surgery.

\section{Methods and patients}

Our study was done in Prince Sultan cardiac center, Saudi Arabia. The study involved 40 pediatric patients undergoing congenital corrective cardiac surgery. Inclusion criteria included pediatric patients (neonates and infants) undergoing congenital corrective cardiac surgery. The exclusion criteria included body weight less than $3 \mathrm{~kg}$, premature neonates, preoperative low cardiac output syndrome, preexisting renal failure, preexisting thrombocytopenia, and preoperative use of milrinone. Before induction of anaesthesia non-invasive monitors (ECG, SpO2) were used. Anaesthetic techniques included a variety of drugs, including ketamine, thiopentone, pancuronium, fentanyl, morphine and sevoflurane, often in combination as needed. After induction and intubation of patients, invasive monitoring such as arterial line and CVP line) were inserted and connected to the transducers. The CPB circuit was primed with an average of $250 \mathrm{~mL}$ of a combination of plasmalyte, $20 \%$ albumin, and whole blood to achieve a hematocrit around $30 \%$. Hypothermia to $22^{\circ} \mathrm{C}-28^{\circ} \mathrm{C}$ and circulatory arrest were used in some patients. For all patients modified ultrafiltration (MUF) was used during cardiopulmonary bypass. The patients were classified randomly into two groups (20 patients each group):

Group A: Milrinone infusion $(0.5 \mathrm{mcg} / \mathrm{kg} / \mathrm{min})$ was started without loading dose at the beginning of CPB and continued postoperatively $(0.5-0.75 \mathrm{mcg} / \mathrm{kg} / \mathrm{min})$ in the pediatric cardiac surgical ICU (PCICU).

Group B: Milrinone was started as a loading dose $50 \mathrm{mcg} / \mathrm{kg}$ over 10 min after aortic declamping and continued as infusion $(0.5-0.75 \mathrm{mcg} / \mathrm{kg} / \mathrm{min}$ ) postoperatively in the pediatric cardiac surgical ICU.

\section{Patients monitoring}

Monitors of patients involved hemodynamic parameters (heart rate, mean arterial blood pressure (MAP), central venous pressure (CVP) and left atrial pressure (in some patient). Arterial blood gases (to check the $\mathrm{PH}, \mathrm{PaCO} 2, \mathrm{PaO} 2$, base excess and deficit, electrolytes and lactate levels) were done through samples withdrawal from arterial line. Central venous gases were done by samples withdrawal from the central venous line. Also monitoring of urine output, urea, creatinine and liver enzymes levels were done. The readings were collected before the beginning of study medication (base line), at $1^{\text {st }}$, $6^{\text {th }}, 12^{\text {th }}$, and $24^{\text {th }}$ postoperative hours in the ICU. Low cardiac output was assessed through (lactic acidosis, low mixed venous oxygen saturation and low urine output. We could not measure the cardiac index as the proper sizes of Swan Ganz catheter for children were not available in cardiac center). Echocardiography was done postoperatively for unstable patients to assess contractility, valvular functions and to exclude pericardial effusion affecting the hemodynamics of patients.

\section{Statistical methods}

Data were statistically described in terms of mean \pm standard deviation $( \pm S D)$. Comparison was done using paired t test. A probability value (P-value) less than 0.05 was considered statistically significant. All statistical calculations were done using computer programs Microsoft Excel 2007 (Microsoft Corporation, NY, USA) and SPSS (Statistical Package for the Social Science; SPSS Inc., Chicago, IL, USA) version 15 for Microsoft Windows.

\section{Results}

Patients

Our study involved 40 patients classified into two groups: Group A, involved 20 patients ( 8 female and 12 male) and Group B, involved 20 patients (10 female and 10 male). No significant difference regarding the age $(P<0.223)$ and weight $(P<0.265)$ of patients in both groups (Table 1$)$.

\section{Surgical Data of patients}

The types of surgical procedures as in Table 2. The cardio-pulmonary bypass time and aortic crossclamping time between the patients of both groups was insignificant $(P>0.05)$ (Table 2 ).

Table 1. Demographic data of patients. Data are presented as numbers and mean \pm SD.

\begin{tabular}{lllc}
\hline Item & group $\mathbf{A}(\mathbf{n}=20)$ & group B $(\mathbf{n}=20)$ & P-value \\
\hline Age(month) & $7.51(3.94)$ & $5.57(4.85)$ & 0.223 \\
Weight $(\mathrm{Kg})$ & $3.55(0.279)$ & $3.97(0.327)$ & 0.265 \\
Sex F/M & $8 / 12$ & $10 / 10$ & - \\
\hline
\end{tabular}

F:female, M: male 
Soliman et al. Journal of Anesthesiology and Clinical Science 2012,

Table 2. Intraoperative data of patients. Data are presented as numbers and mean \pm SD.

\begin{tabular}{lccc}
\hline Item & group $\mathbf{A}(\mathbf{n}=\mathbf{2 0})$ & group B ( $\mathbf{n = 2 0 )}$ & P-value \\
\hline Types of surgery & & & \\
CAVC & 5 & 6 & - \\
IAA repair & 4 & 3 & - \\
TOF+RV/PA conduit & 2 & 1 & - \\
TOF & 2 & 4 & - \\
DORV & 4 & 4 & - \\
TGA (Arterial switch) & 3 & 2 & - \\
CPB(min) & $203(32)$ & $222.1(23.4)$ & 0.158 \\
CC(MIN) & $119.6(15.3)$ & $127.9(11.3)$ & 0.197 \\
\hline CAVC: Complete Atioventic
\end{tabular}

CAVC: Complete Atrioventricular Canal; IAA: Interrupted Artic arch; TOF+RV/PA conduit; Tetralogy of Fallot + right ventricle to pulmonary artery conduit; DORV: Duble Outlet Right Ventricle; TGA: Transposition of Great Arteries; CPB: Cardiopulmonary Bypass; CC: Aortic Crossclamping.

Table 3. Hemodynamic data of patients. Data are presented as mean \pm SD.

\begin{tabular}{|c|c|c|c|c|}
\hline \multicolumn{2}{|c|}{ Item } & \multirow{2}{*}{$\begin{array}{l}\mathbf{A}(\mathbf{n}=\mathbf{2 0}) \text { group } \\
148.9(10.40)\end{array}$} & \multirow{2}{*}{$\begin{array}{l}\text { group B }(\mathbf{n = 2 0}) \\
143.5(11.5)\end{array}$} & \multirow{2}{*}{$\frac{\text { P-value }}{0.256}$} \\
\hline Heart rate & (base) & & & \\
\hline & $\left(1^{\text {st }} h r\right)$ & $146(8.73)$ & $142(13.23)$ & 0.08 \\
\hline & ( $\left.6^{\text {th }} \mathrm{hr}\right)$ & $145.8(10.6)$ & $143.5(7.8)$ & 0.460 \\
\hline & $\left(12^{\text {th }} \mathrm{hr}\right)$ & $144.3(9.5)$ & $143.5(8.4)$ & 0.818 \\
\hline & $\left(24^{\text {th }} \mathrm{hr}\right)$ & $146.9(9.4)$ & $147.3(11.2)$ & 0.251 \\
\hline \multirow[t]{5}{*}{ MAP } & (base) & $63.27(8.51)$ & $57.40(6.90)$ & 0.064 \\
\hline & $\left(1^{\text {st }} h r\right)$ & $65.46(7.51)$ & $56(8.01)$ & 0.001 \\
\hline & $\left(6^{\text {th }} \mathrm{hr}\right)$ & $64.40(7.38)$ & $53.93(5.19)$ & 0.001 \\
\hline & $\left(12^{\text {th }} \mathrm{hr}\right)$ & $60(6.34)$ & $58.33(7.25)$ & 0.378 \\
\hline & $\left(24^{\text {th }} \mathrm{hr}\right)$ & $59.53(5.30)$ & $57.33(3.89)$ & 0.193 \\
\hline \multirow[t]{5}{*}{ CVP } & (base) & $14.40(1.72)$ & $14.53(1.30)$ & 0.818 \\
\hline & $\left(1^{\text {st }} \mathrm{hr}\right)$ & $14.33(1.72)$ & $13.14(1.54)$ & 0.919 \\
\hline & $\left(6^{\text {th }} \mathrm{hr}\right)$ & $13.87(1.85)$ & $14.33(1.8)$ & 0.540 \\
\hline & $\left(12^{\text {th }} \mathrm{hr}\right)$ & $15(1.20)$ & $14.40(1.12)$ & 0.209 \\
\hline & $14.40(1.12)$ & $13.93(1.93)$ & (24th hr) & 0.313 \\
\hline \multirow[t]{5}{*}{ UO } & (base) & $3.38(0.79)$ & $3.55(0.87)$ & 0.610 \\
\hline & $\left(1^{\text {st }} h r\right)$ & $3.50(0.84)$ & $2.76(0.81)$ & 0.001 \\
\hline & ( $\left.6^{\text {th }} \mathrm{hr}\right)$ & $3.99(0.83)$ & $2.81(0.91)$ & 0.001 \\
\hline & $\left(12^{\text {th }} \mathrm{hr}\right)$ & $3.69(0.94)$ & $2.71(0.94)$ & 0.013 \\
\hline & $\left(24^{\text {th }} \mathrm{hr}\right)$ & $3.89(0.72)$ & $2.75(0.77)$ & 0.000 \\
\hline \multirow[t]{5}{*}{ Temp ${ }^{\circ} \mathrm{C}$} & (base) & $36.44(0.74)$ & $36.55(0.53)$ & 0.612 \\
\hline & $\left(1^{\text {st }} h r\right)$ & $36.31(0.9)$ & $36.65(0.80)$ & 0.643 \\
\hline & $\left(6^{\text {th }} \mathrm{hr}\right)$ & $36.53(0.55)$ & $36.53(0.70)$ & 0.978 \\
\hline & $\left(12^{\text {th }} \mathrm{hr}\right)$ & $36.68(0.62)$ & $36.29(0.46)$ & 0.061 \\
\hline & $\left(24^{\text {th }} \mathrm{hr}\right)$ & $36.67(0.49)$ & $36.33(0.57)$ & 0.328 \\
\hline
\end{tabular}

MAP; Mean Arterial Blood Pressure, CVP; Central Venous Pressure UO; Urine Output ( $\mathrm{ml} / \mathrm{kg} / \mathrm{hr}$ ) Temp; Temperature; reading before the beginning of study medication and at $1^{\text {st }}, 6^{\text {th }}, 2^{\text {th }}$ and $24^{\text {th }}$ postoperative hours in the ICU.

\section{Hemodynamic data of patients}

The study showed that the weaning from cardiopulmonary bypass (CPB), was easier in patients of group $A$ than group $B$, in addition to the requirement to more inotropic support, mechanical supports such as extracorporeal membrane oxygenator (ECMO), and pacing during weaning from $\mathrm{CPB}$ and postoperatively in the pediatric cardiac surgical intensive care unit are less in patients of group A than group B.

The comparison of heart rate, central venous pressure, and temperature of both groups was insignificant $(P>0.05)$, but regarding the mean arterial blood pressure, the comparison was significant at the $1^{\text {st }}$ and $6^{\text {th }}$ hour of assessment $(P<0.05)$ but insignificant at other timepoints $(P>0.05)$. Also the loading dose of milrinone in patients of group $B$ was associated with MAP dropping, but for few minutes and managed with dopamine infusion. The urine output was insignificant before starting milrinone $(P>0.05)$, but after starting milrinone increased significantly more in patients of group $A$ in relation to patients of group $B$ at other timepoints $(P<0.05)$ (Table 3 ).

\section{Laboratory data of patients}

There was no significant difference between patients of group $A$ and group $B$ regarding hemoglobin $(P>0.05)$, arterial oxygen saturation $(P>0.05)$ and $\mathrm{PaCO} 2(P>0.05)$ through the timepoints of assessment.

There was metabolic acidosis (diagnosed by $\mathrm{PH}$, base deficit and lactate level), in patients of both groups, but more in patients of group B than that of group A. The lactate level was within normal level before starting the milrinone in both groups with insignificant difference $(P>0.05)$ but at other timepoints the lactate level was higher in patients of group $B$ than group $A$ with significant difference $(P<0.05)$. The comparison of the central venous oxygen saturation was insignificant at the baseline $(P>0.05)$ and lower in patients of group $B$ than that of group $A$ with significant difference at other timepoints $(P<0.05)$ (Table 4).

For all patients, dopamine was added to milrinone during weaning from CPB but, adrenaline was added in 8 patients of patients of group $A$ and added to 14 patients of patients of group $B$, noradrenaline not needed in patients of group $A$ but needed in 3 patients of group B postoperatively in the ICU and the P-value of total inotropic support was signifigant $(P$-value $=0.003)$. Pacing was needed for 5 patients of group $A$ and 6 patients of group B. The ECMO not needed in group $A$ but, only in 2 patients of group $B$ and the P-value of total mechanical support was insignifigant $(P$-value $=0.311)$.

Also, the urea and creatinine were elevated in 5 patients of group $A$ and 7 patients of patients of group B. Liver enzymes levels (AST and ALT), become elevated more than 2 folds on the second postoperative day in some patients of both groups but the difference was insignificant $(P<0.05)$. There were no complications related to milrinone in patients of both groups. 
Soliman et al. Journal of Anesthesiology and Clinical Science 2012,

http://www.hoajonline.com/journals/pdf/2049-9752-1-6.pdf

Table 4. Laboratory data of patients. Data are presented as mean \pm SD

\begin{tabular}{|c|c|c|c|c|}
\hline \multicolumn{2}{|c|}{ Item } & \multirow{2}{*}{$\begin{array}{l}A(n=20) \text { group } \\
14.89(0.90)\end{array}$} & \multirow{2}{*}{$\begin{array}{l}\text { group B }(n=20) \\
15.06(0.86)\end{array}$} & \multirow{2}{*}{$\begin{array}{l}\text { P-value } \\
0.648\end{array}$} \\
\hline $\mathrm{HBg} / \mathrm{ml}$ & (base) & & & \\
\hline & $\left(1^{\text {st }} \mathrm{hr}\right)$ & $14.96(0.93)$ & $14.91(0.81)$ & 0.958 \\
\hline & ( $\left.6^{\text {th }} \mathrm{hr}\right)$ & $14.75(0.77)$ & $15.07(1.19)$ & 0.456 \\
\hline & $\left(12^{\text {th }} \mathrm{hr}\right)$ & $15.12(1.31)$ & $15.08(1.17)$ & 0.932 \\
\hline & $\left(24^{\text {th }} \mathrm{hr}\right)$ & $14.62(0.89)$ & $14.47(0.78)$ & 0.315 \\
\hline \multirow[t]{5}{*}{$\mathrm{SpO} 2$} & (base) & $71.15(10.53)$ & $71.40(11.46)$ & 0.235 \\
\hline & $\left(1^{\text {st }} h r\right)$ & $96.08(4.72)$ & $94.90(3.82)$ & 0.201 \\
\hline & ( $\left.6^{\text {th }} \mathrm{hr}\right)$ & $97.93(1.62)$ & $97.80(1.32)$ & 0.589 \\
\hline & $\left(12^{\text {th }} \mathrm{hr}\right)$ & $98.33(1.29)$ & $98.60(1.50)$ & 0.592 \\
\hline & $\left(24^{\text {th }} \mathrm{hr}\right)$ & $98.80(1.21)$ & $98.52(1.33)$ & 0.651 \\
\hline \multirow[t]{5}{*}{ VSpO2 } & (base) & $51.21(10.19)$ & $49.27(6.06)$ & 0.574 \\
\hline & $\left(1^{\text {st }} \mathrm{hr}\right)$ & $59.62(6.21)$ & $52.37(5.82)$ & 0.014 \\
\hline & ( $\left.6^{\text {th }} \mathrm{hr}\right)$ & $57.73(8.07)$ & $53.00(6.08)$ & 0.025 \\
\hline & $\left(12^{\text {th }} \mathrm{hr}\right)$ & $63.47(6.70)$ & $54.67(5.80)$ & 0.000 \\
\hline & $14.40(1.12)$ & $68.60(6.77)$ & $56.07(6.10)$ & 0.000 \\
\hline \multirow[t]{5}{*}{$\mathrm{PaCO} 2$} & (base) & $4.00(0.44)$ & $4.17(0.31)$ & 0.299 \\
\hline & $\left(1^{\text {st }} h r\right)$ & $4.09(0.36)$ & $4.01(0.29)$ & 0.616 \\
\hline & ( $\left.6^{\text {th }} \mathrm{hr}\right)$ & $4.02(0.32)$ & $4.00(0.27)$ & 0.435 \\
\hline & $\left(12^{\text {th }} \mathrm{hr}\right)$ & $4.11(0.47)$ & $4.13(0.29)$ & 0.871 \\
\hline & $\left(24^{\text {th }} \mathrm{hr}\right)$ & $4.09(0.31)$ & $3.99(0.35)$ & 0.430 \\
\hline \multirow[t]{5}{*}{ Lactate $\mathrm{mg} / \mathrm{dl}$} & (base) & $1.6(0.3)$ & $1.7(0.4)$ & 0.215 \\
\hline & $\left(1^{\text {st }} h r\right)$ & $4.37(0.94)$ & $5.34(0.68)$ & 0.003 \\
\hline & ( $\left.6^{\text {th }} \mathrm{hr}\right)$ & $2.73(0.92)$ & $4.30(0.60)$ & 0.000 \\
\hline & $\left(12^{\text {th }} \mathrm{hr}\right)$ & $2.09(0.65)$ & $3.42(0.52)$ & 0.000 \\
\hline & $\left(24^{\text {th }} \mathrm{hr}\right)$ & $1.35(0.31)$ & $2.42(0.36)$ & 0.000 \\
\hline
\end{tabular}

$\mathrm{Hb}$; hemoglobin $\mathrm{SpO} 2$; arterial oxygen saturation $\mathrm{VSpO} 2$; central venous oxygen saturation $\mathrm{PaCO} 2$; arterial tension of carbon dioxide; base line: reading before the beginning of study medication and at $1^{\text {ts }}, 6^{\text {th }}, 12^{\text {th }}$ and $24^{\text {th }}$ postoperative hours in the ICU.

\section{Discussion}

Adequate cardiac output is an important factor for tissue perfusion, oxygenation and normal organs functions. Several studies have showed that, the low cardiac output syndrome is common after congenital cardiac surgery and leads to increased requirement for inotropes, mainly catecholamines (such as dopamine, dobutamine, adrenaline and noradrenaline) to improve cardiac performance after cardiac surgery. This will increase heart rate and myocardial oxygen consumption, down-regulation of beta-adrenergic receptors, increases the myocardium work, increase in systemic vascular resistance, impair tissue perfusion and development of metabolic acidosis. The acidosis depresses the myocardium, and impairs the sensitivity and response to catecholamines and vicious circle will be developed. The prevention or decreasing the incidence of low cardiac output syndrome will decrease postoperative morbidity and mortality.
In our study, we have started the milrinone infusion early in 20 patients at the beginning of CPB (group A) and compared to the usual use of milrinone in 20 patients after the end of surgical procedures and aortic declamping (group B). We found that the loading dose of milrinone in patients of group B was associated with MAP dropping but it was not severe and for few minutes and managed only with dopamine infusion. The study showed that the weaning from CPB in patient of group $A$ was easier than patients of group $B$. Also, the requirement for dopamine, adrenaline and noradrenaline for hemodynamic support to maintain the main arterial blood pressure from 50 to $60 \mathrm{mmHg}$ was higher and signifigant in patients of group $B$ than in patients of group A. The mechanical support such as pacing and ECMO to the myocardium was needed only in patients of group $B$ because of failure to wean the patients from cardiopulmonary bypass, but statistically was insignificant.

The central venous oxygen saturation was lower in patients of group $B$ than group $A$, and also the lactic acidosis was more in group $B$ than group $A$. This is due to inadequate tissue perfusion as a result to low cardiac output or vasoconstricting effect of catecholamines and the result was impaired oxygen delivery, more oxygen extraction by the tissues and development of anaerobic glycolysis and lactic acidosis.

For patients with decreased urine output in both groups, fluids, furosamide and mannitol doses were given but no response. furosamide infusion was started but not improving well. Finally peritoneal dialysis was used until the complete recovery of kidneys through 7-15 days.

The good results with early uses of milrinone at the beginning of CPB may be due to high level of milrinone in the blood and its effect on the tissue perfusion during and after CPB. This explanation may be supported by study done by Athena F. and his colleges. For neonates undergoing stage I reconstruction of hypoplastic left heart syndrome (HLHS), an initial loading dose of $100 \mathrm{mcg} / \mathrm{kg}$ on CPB resulted in plasma concentrations similar to those observed in other therapeutic settings but, the effect of modified ultrafilration (MUF) is to increase plasma milrinone concentrations by approximately $35 \%$. Assuming that renal clearance is minimal during this time, it is possible that MUF provides both hemoconcentration and a second bolus effect, because blood that was returned to the patients from the venous reservoir contained milrinone [16]. A study was done by Duggal B and his colleges to assess the effect of milrinone on myocardial function in pediatric patients with postoperative low cardiac output syndrome. Fifteen patients with low cardiac output syndrome following cardiac surgical treatment were studied in the tertiary cardiothoracic pediatric intensive care unit. (age range, 0.2-16 months; median, 7; weight, 2.7-11.8 kg; median, 5). Echocardiographic, Doppler-derived, time interval-based index of myocardial performance was used to study cardiac function prior to and while on intravenous milrinone treatment for 18-24 hours. Treatment with milrinone led to im- 
Soliman et al. Journal of Anesthesiology and Clinical Science 2012,

provement in biventricular myocardial function [mean right ventricular index from $0.521 \pm 0.213$ to $0.385 \pm 0.215,(P=0.003)$, mean left ventricular index from $0.636 \pm 0.209$ to $0.5 \pm 0.171$ $(P=0.012)$. No difference was found in the values of heart rate between groups [17].

In 1999, Bailey and colleagues studied the effects of milrinone in 20 children between 3 and 22 months of age with low cardiac output after surgery. All patients received a 50 $\mathrm{mcg} / \mathrm{kg}$ loading dose. In 12 of the children, the loading dose was followed by an infusion of 0.5 to $0.7 \mathrm{mcg} / \mathrm{kg} / \mathrm{min}$. The loading dose produced an average increase in cardiac index of $18 \%\left(\right.$ mean \pm SD $2.0 \pm 0.2$ to $\left.3.4 \pm 0.3 \mathrm{~L} / \mathrm{min} / \mathrm{m}^{2}\right)$ at a mean serum concentration of $235 \mathrm{ng} / \mathrm{ml}$. Mean blood pressure decreased by an average of $12 \%$, from $66.7 \pm 1.4$ to $58.9 \pm 2$ $\mathrm{mm} \mathrm{Hg}$. Heart rate, left atrial pressure, and central venous pressure were unchanged. Based on pharmacokinetic simulations performed with the data from this study, the authors suggest that a short-term, high-dose infusion of $3 \mathrm{mcg} / \mathrm{kg} /$ min for 30 minutes may be beneficial prior to initiation of a $0.5 \mathrm{mcg} / \mathrm{kg} / \mathrm{min}$ maintenance infusion to account for the larger volume of distribution observed in children [5].

A randomized, double-blind, placebo-controlled trial using 3 parallel treatment groups of pediatric patients undergoing cardiac surgery (low dose, $25-\mu \mathrm{g} / \mathrm{kg}$ bolus over 60 minutes followed by a $0.25-\mu \mathrm{g} / \mathrm{kg}$ per min infusion for 35 hours; high dose, $75-\mu \mathrm{g} / \mathrm{kg}$ bolus followed by a $0.75-\mu \mathrm{g} / \mathrm{kg}$ per min infusion for 35 hours; or placebo). The authors concluded that the use of high-dose milrinone after pediatric congenital heart surgery reduces the risk of LCOS[15].

A study was done by Nineteen patients with decompensated heart failure underwent right heart catheterization and were randomized to receive an intravenous infusion of milrinone at a rate of $0.50 \mu \mathrm{g} / \mathrm{kg} / \mathrm{min}$ with $(\mathrm{n}=9)$ or without $(\mathrm{n}=10)$ a preceding $50 \mu \mathrm{g} / \mathrm{kg}$ bolus. Pulmonary capillary wedge pressure, cardiac index, and plasma milrinone levels were measured serially over 24 hours. One patient randomized to a milrinone bolus demonstrated a marked decrease in blood pressure and was discontinued from therapy. They concluded that milrinone infusion without a bolus appears to be a rapidly effective inotropic strategy that may have an improved safety profile during the initiation of therapy compared with a continuous infusion strategy initiated with a bolus [18].

\section{Conclusion}

Early use of milrinone in pediatric patients undergoing cardiac surgery lead to easy weaning from $C P B$, decreased the requirement for pharmacological and mechanical support and decreased the incidence of low cardiac output syndrome after pediatric cardiac surgery without complications related to milrinone in our study patients.

\section{Author's information}

${ }^{2}$ Ein shams University, Egypt.

${ }^{3}$ Prince Sultan cardiac center, Riyadh, Saudi Arabia.

\section{Competing interests}

The Authors declare that they have no competing interests.

Publication history

Received: 18-June-2012 Revised: 04-July-2012

Accepted: 13-July-2012 Published: 23-July-2012

\section{References}

1. Wernovsky G, Wypij D, Jonas RA, Mayer JE, Jr., Hanley FL, Hickey PR, et al.: Postoperative course and hemodynamic profile after the arterial switch operation in neonates and infants. A comparison of low-flow cardiopulmonary bypass and circulatory arrest. Circulation 1995; 92;(8.);2226-35. | Article | PubMed

2. Wright EM, Skoyles J, Sherry KM: Milrinone in the treatment of low output states following cardiac surgery. Eur J Anaesthesiol Suppl 1992; 5;(21-6. | PubMed

3. Ramamoorthy C, Anderson GD, Williams GD, Lynn AM: Pharmacokinetics and side effects of milrinone in infants and children after open heart surgery. Anesth Analg 1998; 86;(2.);283-9. | Article | PubMed

4. Chang AC, Atz AM, Wernovsky G, Burke RP, Wessel DL: Milrinone: systemic and pulmonary hemodynamic effects in neonates after cardiac surgery. Crit Care Med 1995; 23;(11.);1907-14. | Article | PubMed

5. Bailey JM, Miller BE, Lu W, Tosone SR, Kanter KR, Tam VK: The pharmacokinetics of milrinone in pediatric patients after cardiac surgery. Anesthesiology 1999; 90;(4.);1012-8. | Article | PubMed

6. Feneck RO: Intravenous milrinone following cardiac surgery: I. Effects of bolus infusion followed by variable dose maintenance infusion. The European Milrinone Multicentre Trial Group. J Cardiothorac Vasc Anesth 1992; 6;(5.);554-62. I Article I PubMed

7. Holmberg SR, Williams AJ: Phosphodiesterase inhibitors and the cardiac sarcoplasmic reticulum calcium release channel: differential effects of milrinone and enoximone. Cardiovasc Res 1991; 25;(7.);53745. | Article | PubMed

8. Katz AM: Interplay between inotropic and lusitropic effects of cyclic adenosine monophosphate on the myocardial cell. Circulation 1990; 82;(2 Suppl.);17-11. | PubMed

9. Kauffman RF, Schenck KW, Utterback BG, Crowe VG, Cohen ML: In vitro vascular relaxation by new inotropic agents: relationship to phosphodiesterase inhibition and cyclic nucleotides. J Pharmacol Exp Ther 1987; 242;(3.);864-72. I Article I PubMed

10. Polla B, Cappelli V, Canepari M, Zanardi MC, Reggiani C: Direct depressant effect of phosphodiesterase inhibitors on ATPase activity of rat cardiac myofibrils. Can J Physiol Pharmacol 1995; 73;(5.);661-4. | Article I PubMed

11. Chatterjee K: Phosphodiesterase inhibitors: alterations in systemic and coronary hemodynamics. Basic Res Cardiol 1989; 84 Suppl 1;(213-24. | Article | PubMed

12. Ringe HI, Varnholt V, Gaedicke G: Cardiac rescue with enoximone in volume and catecholamine refractory septic shock. Pediatr Crit Care Med 2003; 4;(4.);471-5. I Article I PubMed

13. Shipley JB, Tolman D, Hastillo A, Hess ML: Milrinone: basic and clinical pharmacology and acute and chronic management. Am J Med Sci 1996; 311;(6.);286-91. | Article | PubMed

14. Young RA, Ward A: Milrinone. A preliminary review of its pharmacological properties and therapeutic use. Drugs 1988 36;(2.);158-92. | PubMed

15. Hoffman TM, Wernovsky G, Atz AM, Kulik TJ, Nelson DP, Chang AC, et al.: Efficacy and safety of milrinone in preventing low cardiac output syndrome in infants and children after corrective surgery for congenital heart disease. Circulation 2003; 107;(7.);996-1002. | Article I PubMed

16. Zuppa AF, Nicolson SC, Adamson PC, Wernovsky G, Mondick JT, Burnham $\mathrm{N}$, et al.: Population pharmacokinetics of milrinone in 
Soliman et al. Journal of Anesthesiology and Clinical Science 2012,

neonates with hypoplastic left heart syndrome undergoing stage I reconstruction. Anesth Analg 2006; 102;(4.);1062-9. | Article | PubMed

17. Duggal B, Pratap U, Slavik Z, Kaplanova J, Macrae D: Milrinone and low cardiac output following cardiac surgery in infants: is there a direct myocardial effect? Pediatr Cardiol 2005; 26;(5.);642-5. | Article | PubMed

18. Baruch L, Patacsil P, Hameed A, Pina I, Loh E: Pharmacodynamic effects of milrinone with and without a bolus loading infusion. Am Heart $J$ 2001; 141;(2.);266-73. | Article | PubMed

\section{Citation:}

Soliman R, Yousef H, Ragheb A, al Qethamy H, Alghadam $\mathrm{F}$ and Elgamal G: Comparison of early and late intravenous infusion of milrinone in pediatric patients undergoing cardiac surgery. journal of Anesthesiology and Clinical Science 2012, 1:6.

http://dx.doi.org/10.7243/2049-9752-1-6 